Journal of Social Sciences 6 (3): 459-467, 2010

ISSN 1549-3652

(C) 2010 Science Publications

\title{
Geopolitical Constructs Understanding and Survey with Constructivism Geography Approach Case Study: IRI and Its Confronting Challenges in Central Asia
}

\author{
${ }^{1}$ Zahra Pishgahifard, ${ }^{2}$ Mostafa Rashidi, \\ ${ }^{3}$ Mohammad Shabanifard and ${ }^{4}$ Mohammad Reza Abdullahpour \\ ${ }^{1,2}$ Department of Geography, Political Geography, \\ ${ }^{3}$ Department of Geography, Urban Planning, \\ ${ }^{4}$ Department of Law and Political Science, Public Policy Making, \\ University of Tehran, Iran
}

\begin{abstract}
Problem statement: After dissolution of Soviet Union, both of political geography system and dominance ideational structure have deconstructed in central Asia region. In year of 1979 with revolution, Iranian actors was accepted the Islamic republic system in their country, so new actors, structure and exigencies were revealed in Iran and central Asia relations, that cause create new challenges in confronting of Islamic republic of Iran government. Our fundamental question in this research is that: How geopolitical constructs have constituted confronting challenges for Islamic republic of Iran in Central Asia region? Approach: Therefore in this study we tried to explain the question in geographical framework and constructivism approach (on ground as constructivism geography). We had utilized qualitative research method and hermeneutic-positivist procedure in this study. As attention implicated question, the purpose of this article is understand challenges how constitute in reason of geopolitical constructs. Results: Differences in geopolitical constructs, between Iran and countries of central Asia region and also being harmonious construct, these countries with the present actors in the region, has caused an opposition in regional anarchic system between IRI and these countries in region and actors in the region and also form of distribution of capabilities between actors which has caused challenges for IRI. Conclusion: For following its goals against, high level fruition enemies of IRI like USA, Israel and Russian, China competitors from distribution of capabilities in national and international caused many challenges and double-deficiency for IRI.
\end{abstract}

Key words: Constructivism, geography, geopolitical construct, Islamic republic of Iran, Central Asia

\section{INTRODUCTION}

After ending of cold war, world geopolitical map changed in Central Asia, Caucasia and Eastern Europe region. New countries appeared on the world geopolitical map, as result that new exigencies revealed. New autonomous republics were appearing in central Asia that was parts of Soviet Union, which were different from the former political units of Soviet Union. So at this time, the world faced countries with their particular geopolitical structures and specific patterns in this region and global arena that some were joint and some were different. Before the autonomous of central Asia republics, new ideological-political discourse dominant in Iran after revolution of 1979, as this discourse were different from the monarchical and amicable government of Iran and in view of with western world, it had Islamic nature. Now out of constitution of these processes we confront a new political geography form that cause new discourse in regional interactions, specially about relations between Islamic republic of Iran and central Asia countries. Iranian agents have reproduced new, different deeply political identity in their Islamic-Shiite past, as well new actors have attended like, USA, ISR, TUR, CHI in the region. Beside all above, Russia, the remainder of Soviet Union has attended to the arena as an identified actor with new identity, agency, ideational and structure. With consideration to these changes, it is necessary for us to present an analysis of Islamic Republic of Iran relations with the central Asia countries by survey and understanding geopolitical constructs in the region, ultimately we have exhibited to understand confronting challenges in this region through geographical framework and constructivism approach. So we want to answer the fundamental 


\section{J. Social Sci., 6 (3): 459-467, 2010}

question of this research: How geopolitical constructs have constituted confronting challenges for Islamic republic of Iran in central Asia region?

We have utilized qualitative research method and hermeneutic-positivist procedure in this study.

Constructivism an approach for analysis relations between countries: Constructivism from philosophical viewpoint to be applied, which in basis on the whole knowledge and humanities phenomena have constituted, although these constitutions are socially and collective intentionality (Salimi, 2007). Ontology is part of metaphysics, the branch of philosophy that studies the nature and operation of reality or being. Ontology is principal focus of constructivists (Moshirzadeh, 2007) so that, constructivists, ontologically believes that social facts are subjective affairs which includes rules, laws, ideas. It concerns the set of specific assumption about the nature of existence underlying a theory or system of ideas, beliefs about what exist and can be observed and therefore known, these concepts have constituted in during time and in the particular geographical space. Due impressed different process till have been form and present structure. This change and influence is not stagnant but constantly is reproduction and transformation, so that, constructivists see the social world to became (Motaghi and Kazemi, 2007). as Kubalkova (2001) mention, constructivists know the international world "an endless constitution project" that believes this constitution have provided on background of textual perceptions this modifying perceptions show forms from Ideas and images in any geopolitical space and any time which constitute the identity of people and groups. So that, conscious creature points at history, corporate joint memory, territorial stage, then distinct himself from the other who are not like him. In all, identities configure in base on texts (Jenkins, 2004). So that, actors distinct themselves by these Ideas and images from the others. Identified actors act on the basis of ideas and images of themselves by the others in text space in order to take benefits based on these ideas and identities. Wendt (1994) believes that the benefit of these ideas and identities consist of four benefits: (1): Material security: distinction from other actors. (2): Ontological security: Liking for stable social identity. (3) Recognition: as an actor by the others, not by sheer force. (4): Development: Safeguarding the interest of the people for the better life that government are known responsible in collectively level. Any actors look for his benefits on basis of his identity's structure. As identities figure the benefits and acts of actors. Understanding of these facts is really important for analyzing the foreign policy and international acts of the actors. Therefore, Wendt (1992) knows the identities as base of the benefits and believes that there is no benefits without ideas, no facts without material origins (Wendt, 1999).

Geography, geopolitical constructs and understanding of the distributions of capabilities: Geography is the science of reciprocal relation between human and nature (Shakouhi, 2003). If we consider the Idea of Griffith Taylor as the main point, "geography involves three level as Human, natural environment and interaction between these two. So it discuses about human, social power, identity and cultural, also discusses the natural environment, facilities, resource, opportunities and the limitation rising from that and the equipments to profit by such as technology and manmade phenomena and. Geography in its ontology face both of human affairs (social, political, cultural) which are subjective and collective intentionality, although environmental-natural affairs like resources, geopolitical location and, which have objective ontology and independent from mind. Beside these mutual facts, there is synthetic aspect caused by the interaction between human and natural environment, that to be brought forth for discussion with complicated subjective-objective ontology. So that, geographers, especially geopoliticians confront with subjectiveobjective phenomena. They need to recognize its (epistemology) profoundly to accomplish explanation and conceptualization and take a middle course in methodology, which is hermeneutic-positivist method. Therefore, geopolitical structures should be recognizing as a body of ideational structures, interests and material structures. In this article following mentioned investigative direction. We analyze two kind of geopolitical constructs.

Basic geopolitical construct: as we analyze one region and its relations with a neighboring country, Islamic republic of Iran. In this study we consider these countries and their internal system as the start of all acts, as the corporate-national identities. We know this geographical-political unit as the basic geopolitical construct in the discussion of region actions. Country is the result of body of constitution process in a period, in specific society and spacial-place framework, which appeared in 1648 under Westphalia agreement for the first time as modern (Naghibzadeh, 2005). Hafez Nia says" country is equal to state" but more politicalgovernance distinguished (Hafeznia, 2001). In other hand Mojtahezadeh and Hafeznia (2008) consider country as the state which involves government, territory and nation. Wendt (1999) says "state is a 
place" according to Michael Mann and believes that state have spacial scope. This spaces itself has unique cultural-social geographical spaces. This cultural geography is based on description, analysis, differential and similarities of language, religion, economy, government and other cultural phenomena in different places (Jordan-Bychkov and Rowntree, 2001). Cultural geography follow a comprehensive analysis that how specific identities groups constitute confront other identities groups and how different landscapes are reflection other identities groups (Norton, 2000).

In basis this same cultural geographies and spaces as Foucault mentioned are impractical down seduction to each other's (Soja, 2008), that figure different ideational structures in collective-national identities, so follow different interests with other actors and interpret material structures in basis of Ideas and their images. Tracing social different and inequality in throughout the world to be revealed networks, relations, groups and identities as organized systematically, although against sheer social analysis, it can be analyzed not just socially but Geographically (Del Casino, 2009). This culturalsocial mechanism, which is geographical constitutions, occasionally can be so obvious that won't be recognized easily and maybe as unconsciously. Foreign policies, which are based on different cultural, social and political geography, are set of speeches and behaviors that are spacial-place framework different and so that are known as geopolitical Deeds. Deeds are applied to speeches and behaviors (Onuf, 1989), which named Geopolitical deeds because of their origin in geographical spaces and their spacial scope. This term geopolitical deeds create by second and third authors of this article. So that every state is a geographical construct or "geopolitical" like unique features and separate from other country and states.

Countries in the way of fallowing their interests caused by their ideational structures faced many material and structural limitation and opportunities, which make them, change their policies and reproducing their identities due to follow interests in international relation. They need investments, technology, diplomacy and interaction with other actors in order to overcome their material limitation like interests and positions; they take changes in their ideational structure in order of structural limits with consideration to capabilities. In basis of realism principle when a country has least interests of distribution of capabilities in a region or international geopolitics arena, as well the most ideational differences with dominant anarchic system in region and the world, for development has the most need to review and redefinition of its ideational structures and persistent procedure of its interests, Because as Wendt (1999) says, the government that has policy, contrary to the international anarchic system, won't have appropriate performance and it has the most challenges. Now if we consider these particulars with low fruition a country from distribution of capabilities, we face a multiple deficiency, consequently, a multiple challenge would obstruct the mentioned government. Actors try to redefine themselves and the others in order to establish anarchic system based on their ideational structure because of the differences between geopolitical structures especially ideational structures. They utilize their capabilities in order of competition with competitors and hostility toward enemies.

Coalition or floating geopolitical construct: This construct is based on almost similar spaces or, are originally based on the history and the form of constitution of these geographical places or are the result of deliberated acts of actors, specially colonizers in recent decades and countries in order of making harmony the plurality geographical spaces for capitalism system, we named this construct coalition because it constitute as self-fulfilling and constitutive form to coalition between basic constructs (Selffulfilling geopolitical construct) Or as deliberative basic constructs or Coalition self-fulfilling construct transformed and making harmony in direction with each other or with other agents groups ( Other-fulfilling coalition construct), (to understand the overall of constructs in this part, pay attention to Fig. 1).

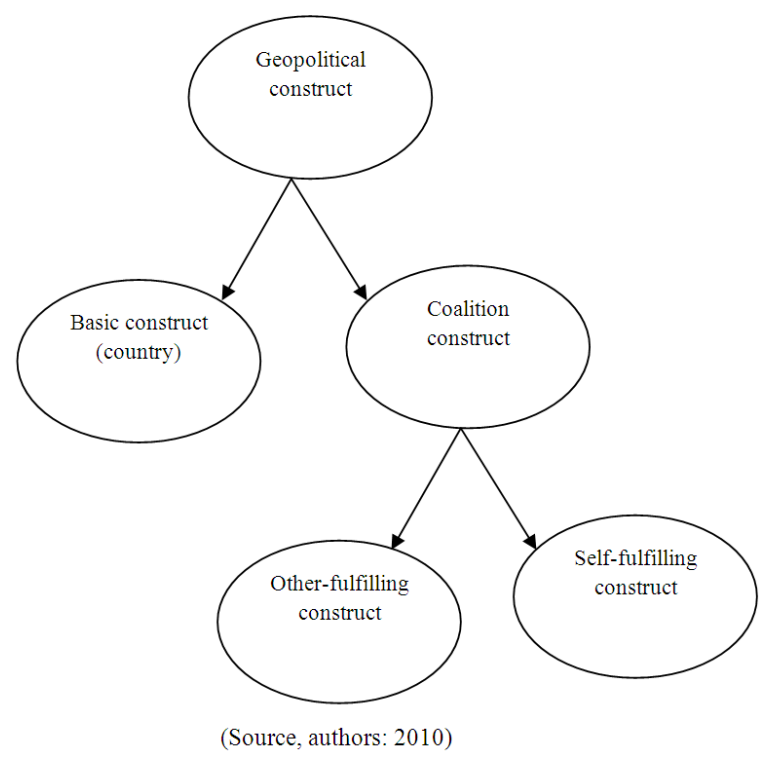

Fig. 1: Conceptual model of geopolitical construct 
Coalition or floating constructs in this article as case study, means collection of similarities in central Asia region and between countries or their actors in this region (for example, construct: Being Turk between Turkey as the regional actors and Turkmenistan, Uzbekistan and, as the countries in the region). Now considering all above, we analyze different geopolitical construct in Central Asia and the challenges for IRI.

Geopolitical constructs and the challenges for IRI: As this article emphasize on IRI and its challenges, first we consider geopolitical constructs of Iran.

\section{Iranian basic geopolitics construct:}

Historical-geographical Identity: With consideration to position and geographical space, Iranians had have relations with different groups and nations because of the geographical position (Hafeznia, 2001), this nations and tribes had came to Iran as invasion or immigration, so that there have been many interactions in Iran between different nations. Geopolitical position of Iran has caused Iran to be neighbor with power and invaders like Rome and Turkestan in ancient age, In Islam era and in contemporary age also, Iranians have faced tribes and nations Turk, ottoman, England, Russia and USA, which wanted to interference because of its importance position (Hafeznia, 2001). The importance of Iran, Gradually, got deeply Image and idea, that they are obvious in all vestiges and maps of Iranian geographers, Iran have imaged in the center of world and always it is the best land and climate in world (Shakouhi, 1994), even in literatures and Persian poetries. This geographical-legendary belief is the central point of this territory "Iranwij" or "Khoniras" which is legacy from Fereydoun to Iranians ancestor come down by inheritance to Iraj (Kheyrandish and Shayan, 1991), have formed the concept of "holy land" in mystical literature of Iran. so it is not strange for Iranian to have an "Iran axis" view to the world, they are so fanaticism that is not comprehensible for the foreigners (Fuller, 1991). This image have emerged dramatically after discovery of oil and gas resources and also flow of world war 1 and specially world war 2 which is known as bridge victory for Iranian, to improve the geopolitical position of Iran. Iran Importance and the ideas about it has constituted other ideas such as being afraid of foreign dominance, imagination of foreign plot and proteges of politicians, this idea have became firm in Iranian personal lives (Hafeznia, 2001) this idea have had disadvantages in political history of Iran, such as, frustration of Mosaddege's government after the Iran oil became nationalized (Katouziyan, 2008). Iran's history that is based on this country's special geography has influenced the firming and expanding of ideational structure of these actors. Iranian always remember their splendid kings, like the great Cyrus, Dariush and prophets like Zoroaster (Razi, 1948) and they are proud of their magnificent dynasties before and after Islam, that is how they believe in their superiority, from the other hand, they never forgot the defeat of foreign interference and invaders, especially in contemporary age. That is why they not eager to have relations with foreign countries, in other direction they have doubtful to have relations with foreign countries. In Iran's history, these qualities have caused to appear movement like "Shoubieh" the main purpose of this group was revival of Iranian and Islamic real cultural against of Arabs that humiliated Iranians (Fuller, 1991; Pirouz, 2007) and also we should mention the Islamic revolution of 1979 .

Ethnical-lingual identities: The name of "Iran" has ethnical origin, which according to archeology and historical theories presents the race that was the ancestors of Iranians. These nations which are known as "Arians", entered Iranian plateau in 2000 B.C and dominant a new cultural and civilization by cause escape other tribes and nations out of territory or combine them (Hafeznia, 2001). Despite of the Arabs Invasion and entering of Turks to Iran, The Iranian identity and cultural still exist and remain by the pivotal role of Persian language, Nowadays Nations such as Pars, Lour, Kurd, Gil know themselves from Arian generation. These people especially Turks of Azerbaijan (which many researchers believes as Arian generation), Turkmens, Arabs, know Persian as the official language of the country, but talk in their own language unofficially. Here we consider 'Persian language" and "Persian originality" as the main reason for Iranian to know them different from the other relations. Also it should be mentioned that Iranian nations find their identity mostly in "Farsi" language as criterion language (not as the conclusive national language).

Islamic identity and ideology of IRI state: Islam, as one of the important idea maker factors for the main identity Iranians have played an important role ideational structure constitution of Iranian actors. During 1400 years, Islam have influenced Iranian believes and ideas deeply have been influenced in the Iranian geographical framework (Motahari, 1983), in contemporary age, new meanings have appeared as "Islamic rise" circulated between Muslims especially Iranians. Islamic rise, in fact, tries to revival religion commitments, which is opposed to many of modern world's ides. This rise has involved an extended geographical area (Berger et al., 1999). This political 
idea of Islamic resistance against the west cultural is obvious in ideas Seyed Qotb in Egypt, Aboulali in Pakistan, Khomini (and also Nawab Safavi) in Iran, which have led the discourse of "fighter Islam" and publicized the idea of resistance against dominant of liberalism and democracy of the west (Esposito, 1990). This contemporary rise, according to the idea of "Mohammad Eghbal", Muslim and philosopher, who believes Islam substantial foreign does not concentrate on a specific region or country and mentions Muslims all over the world. This new idea which is based on Islam's traditional concepts, has presented a new definition of "opposition of blasphemy and faith". Qotb (1999) according to the ignorance theory has denied all the present nations and disciplines, so that he knows his society like the Mecca state of Arabs before Islam. Islamic revolution of 1979 is based on this idea of "Islamic rise" and political idea of Islamic resistance and we can see that in the Khomeini talks (who is the leader of this new idea of Islamic residence) and also it is obvious in constitutional law of Islamic republic especially in preface of principle rule 11 . We should know that Islamic republic of Iran also emphasize on "Islamic rise" because of the constitutional law of Islamic republic of Iran, the talks of Khomeini and the present leader of IRI, khamenei. For instance, Khomeini in one of his talks has called countries like Turkey as the assistance of "ignorance system" and imperialism. He believes that, this is one of the duties of Islamic state to rescue the Muslims from the Imperialism system of these countries (Mousavi Khomeini, 1983), also Ayatollah Khamenei use phrases like arrogance usurper America and emphasize to annihilate Imperialism system and Israel form the Islamic nations. According to all above IRI identity is based on ideas, geopolitical sensitiveness, Historical, ethnical-lingual and Islamic-ideological, this identity generally is a revisionist and soliciting geopolitical construct in global geopolitical system and especially as regional. Furthermore, IRI is revisionist about the west discipline and look for a change (revisionist anarchic system), also IRI follow a cooperative anarchic system for different relations, without any attention to their governments.
Now we analyze the challenges for Islamic republic by reviewing the self-fulfilling and otherfulfilling floating construct in central Asia, different regional and interregional actors, realizing the type of dominated anarchic system in the region and the form distribution of capabilities between Iran and other actors in region.

\section{Coalition geopolitical constructs in Central Asia and IRI challenges: \\ Ideational construct in central Asia:}

Cultural, ethnical and linguistic construct: After the autonomous, people of central Asia tried to supersede socialism for the political, economical, social ideology to define their national identity. People of central Asia had no separate identity and culture before autonomous and used to be led in groups, tribes and sometimes by through the religion. Establishing a republic has made the matter of identity and culture complicated (Vaezi, 2007). One of the regional differences in central Asia is that the political borders are not adapted to the ethnical, linguistic and cultural frontiers that have replaced republics of these regions in artificial ethnical-cultural territory of political units (Hafeznia et al., 2007). Although this political distribution, from linguistic aspect, except most of the Tajiks and 5 percent of Tajiks in Uzbekistan, people in central Asia talk in Turkish. This means Iran doesn't have enough linguistic association with the people of this region and constitute challenges for Iran. On the other hand, Turkey, as Iran's rival, has used this opportunity by disseminating 'Pan Turkism". Turkey always has paid special attention to the central Asia and tries to influence this region by its historical background and Turkish cultural and Turk nationalism ideas. Pan Turkism used to be disseminated from Turkey and by the support of west policy hubs, in order of confusion in Soviet Union, which turned into a serious idea after the cold war and independence of Turk-tongue countries. This Turkish exaggerative nationalism and lingual difference between central Asia countries and Iran (except Tajikistan), is a serious challenge for Islamic republic of Iran (Table 1).

Table 1: Ethnicities and languages in Central Asia (in percent)

\begin{tabular}{|c|c|c|c|c|c|c|c|c|}
\hline \multirow{2}{*}{$\frac{\text { Country's name }}{\text { Uzbekistan }}$} & \multirow{2}{*}{$\begin{array}{l}\text { Ethnic } \\
72\end{array}$} & \multicolumn{7}{|c|}{ Other minorities } \\
\hline & & $\begin{array}{l}\text { Russia } \\
8\end{array}$ & $\begin{array}{l}\text { Tajik } \\
5\end{array}$ & $\begin{array}{l}\text { Kazakh } \\
4\end{array}$ & Tatar & $\begin{array}{l}\text { Other } \\
8\end{array}$ & & \\
\hline Tajikistan & 62 & $\begin{array}{l}\text { Uzbek } \\
24\end{array}$ & $\begin{array}{l}\text { Russia } \\
8\end{array}$ & $\begin{array}{l}\text { Tatar } \\
2\end{array}$ & $\begin{array}{l}\text { Azeri } \\
1\end{array}$ & $\begin{array}{l}\text { Other } \\
3\end{array}$ & & \\
\hline Turkmenistan & 72 & $\begin{array}{l}\text { Russia } \\
10\end{array}$ & $\begin{array}{l}\text { Uzbek } \\
9\end{array}$ & $\begin{array}{l}\text { Kazakh } \\
3\end{array}$ & $\begin{array}{l}\text { Ukraine } \\
1\end{array}$ & $\begin{array}{l}\text { Other } \\
5\end{array}$ & & \\
\hline Kazakhstan & 40 & $\begin{array}{l}\text { Russia } \\
38\end{array}$ & $\begin{array}{l}\text { German } \\
6\end{array}$ & $\begin{array}{l}\text { Ukraine } \\
5\end{array}$ & $\begin{array}{l}\text { Uzbek } \\
2\end{array}$ & $\begin{array}{l}\text { Tatar } \\
2\end{array}$ & $\begin{array}{l}\text { Uyghur } \\
1\end{array}$ & $\begin{array}{l}\text { Other } \\
6\end{array}$ \\
\hline Kyrgyzstan & 52 & $\begin{array}{l}\text { Russia } \\
22\end{array}$ & $\begin{array}{l}\text { Uzbek } \\
13\end{array}$ & $\begin{array}{l}\text { German } \\
2\end{array}$ & $\begin{array}{l}\text { Tatar } \\
2\end{array}$ & $\begin{array}{l}\text { Other } \\
7\end{array}$ & & \\
\hline
\end{tabular}




\section{J. Social Sci., 6 (3): 459-467, 2010}

Also, despite of this fact that most of the people of central Asia are Muslims, they are mostly Sunnite and Hanafi (Falahatpisheh, 2001). So that, from religious aspects, Iran never had enough influence that could had in Shiite countries and this is another advantages for Turkey. This challenge is floating self-fulfilling or selforganizing and is a result of linguistic-religious constitution in this region.

Political Ideology construct in central Asia: Actors ideology in central Asia after dissolution, in two level political and social have constituted as integrated with approach of Secularism and moderate Islamism, in political scale with attendance of government and all constituted institutions in central Asia republics emphasize on secularism nature. Although the leaders of these countries are aware of social tendency to the moderate Islamism and roles in constitution of cultural identity of society. Therefore, government's ideology in frontiers in central Asia is based on secularism and people's religious is valued. But about foreign policy, governments try to emphasize on secular and liberal values in order of following their national interests. Nowadays, all central Asia countries' fundamental law respects this norm that religious is separated from politics, though Islam is popular religion in central Asia, acceptable Islam for politicians, in fact is a way to take interests of religious to supply lacks (Akiner, 2003). According to witnesses, internationally, political actors in central Asia are worry about national interests more than Islam itself and any instability is a serious danger, so that why religion hasn't played any effective role to organize political-cultural bases in these countries (Matveeva, 1999). But it should be mentioned that since 1989, religion sects especially Islam are allowed to be attended in mass media (Yazdani et al., 2007). Nowadays, there are three Islamic movements in central Asia: Islamic movement of Tajikistan, which is lasting as an legal party, Islamic movement of Uzbekistan, which is known as a terrorist organization because of its measures and the third one is Altahrir party, which is active in Uzbekistan and Tajikistan mostly and although it knows itself as a political party, it's a kind of ideological movement. This party is an extravagant kind and isn't limited to any military rules. Their aim is to organize Islamic caliphate. This group, unlike the Islamic movement of Uzbekistan, is not known as a terrorist group (Salimi and Abadi, 2008). Although all above, regarding to the raise of liberalism and secularism in region, we can say that different religions in central Asia, Islam included, have had no influence on the regional politics (Yazdani et al., 2007). Central Asia countries are looking for development and try to find it in liberalism economy and free-marketing and west-countries investing capital, specially united states. Therefore, irreligion processes are more effective in central Asia governments, which are supported by USA, Israel and Turkey. For instance one of United States' goals is to strengthen the countries in region toward developing the west-democracy and economy of free-market (Vaezi, 2007). Also, Israel tries to weaken religion and prevent Islam from being expand in the region (Alimoradi, 2009). So, we can say that secular ideology is one of the most important political ideas in this region and according to the Islam-tendency of Iran and this country's idea of "Islamic resistance", we should say that Islamic republic of Iran has faced a challenge ideologically. This structure is other fulfilling, which is rising because of dissemination of west culture the development of related organizations and the power of supervisors and supporters of secularism ideology, in order of purifying the region for a consumer market and revenue its benefits.

Material construct: Source, consumer market, position and availability although central Asia region is surrounded in lands and is not linked to the oceans and free water, it has really important petrol and valuable metals resources. To send them to the consumer markets, we should consider land communication network, railways, telecommunication network, software substructures such as banking and insurance system, costumes laws and at a glance, electronic commerce and other legal matters. From the other hand, exportation the resources of central Asia to the consumer markets, make exportation incomes and this materials are used to import necessary goods and services (Lussac, 2008). Central Asia region is the exporter of crude materials and the importer of consumer goods. Therefore, this region needs technical-engineering services for exploitation of mines and also is a consumer market for foreign goods; this region needs connection routs for import and export. So that there are two important railways, one through central Asia-Caucasia-Europe from east to west and another one is transportation railway from north to south. Islamic republic of Iran annihilated the structures of cold war and linked Trans-Iranian Railway to the trans-central Asia railway by connecting Mashhad railway to Sarakhs and Turkmenistan and connecting Tajan railway to Sarakhs in 1996, these railways, linked Iran to the oceans. Also Iran reduced the area between Bandar Abbas in Persian Gulf with central Asia about 1000 $\mathrm{km}$ by constructing the Bafgh-Bandar Abbas and Bafgh-Mashhad railways. Land routes in central Asia 


\section{J. Social Sci., 6 (3): 459-467, 2010}

are linked to Iran by Eshgh Abad-Tajgiran in 2006 (Amirahmadiyan, 2008). Despite of vicinity of Iran and central Asia and connection possibility of connection for the region's country through Iran with the oceans and translocation of energy and natural gas through Iran (from south of Caspian sea) to the Europe (Amirahmadiyan, 2003), also providing some technical-engineering services and some consumer goods of central Asia countries, Iran have had the least share of this opportunities in compare of countries like USA, Turkey, Russia and the reason of this challenge is relating to the ideational structures of central Asia region and the opposition of these with geopolitical structures of Iran.

Dominated anarchic system of central Asia region, distribution of capabilities and understanding of challenges for Islamic republic of Iran

Generally, ideational structure in central Asia is based on language, ethnically, Turk culture, Pan Turkism, Sunnite Islam, Islam in social domains and secularism, while Iran is a country with Persian ideational structure, (based on Farsi language), Shiite Islam, relation of religion with all domains of politic, society, economy. and revolutionary approach for protecting of Muslims and the needy and antisecularism. From linguistic aspects, Iran is related to Tajikistan; from religious aspects, because of differences between Hanafi and Shiite religion and the different believes of these two about political Islam, Iran is not able to be a self-fulfilling factor in relations with west countries and capital investing in this case involves huge expenses and is not advantageous. In governmental ideology aspects, if we consider the idea of "risen Islam", that Islamic republic is one of its results, all the governments of central Asia region are assistances of ignorance Theory the main point of Risen Islam and blasphemy and as ayatollah Khomeini says, Muslims should be released. So that we can say Iran have an ideology and revision approach about the region, which has basic differences with the dominated anarchic system in central Asia region and with actors like USA, Israel, Turkey and Russia even and China. So that as the anarchic system of a country does not conform with the international or regional dominated anarchic system and adaption would involve huge expanses, Islamic republic needs to accept the expanses and the challenges caused by These challenges themselves, cause further challenges, because equations structures forms on these ideational structures and ideas and believes of actors about each other.

Islamic republic of Iran is a regional power and as we all know, is effective in its domain; this country faces international and regional powers in its region, which are internationally powerful. These countries are rated by the power efficiency level, internationally and regional, as: USA, Russia, china, Turkey and Israel. Countries such as USA and Israel are the most important enemies of Iran and try to reach their goals by military, economic, political and cultural powers as Integrated and to marinate Iran. This country have made a floating construct based on ideas of secularism, liberalism and free-market and tries to extend their American-Israeli approach by negative publicity against Islam and Iran as an Radical Islamism country. Tendency of central Asia countries to this political ideology has paved the way for cooperation, capital investing and economical equations with these countries.

Also turkey is the completer of this process because of similar national-linguistic-religious constructs with the central Asia countries and cooperation with United States and Israel. This union, which is based on floating geopolitical constructs, has turned all mentioned potentials of Iran to challenges; potentials such as adjacency of Iran and central Asia, energy translocation to the European union and other countries in the world and. Russia is a secular country too and challenges of this country with USA changed to national interests after the decline of the Soviet Union. The construct of the central Asia region have no interests for this country. Russia is just following its interests and in this way, sometimes faces challenges with Iran. For example, while everything is fitting for Iran to translocation gas from central Asia to Europe, Russia, USA and Israel sometimes avoid it; USA and Israel because of ideological oppositions and Russia because of problems that may face in the export of gas from Russia to the European Union (Shekari, 2006). Also China has secular system and tries to preserve the peace of the region, provide energy for china and prevent any Islamic foundation in region, because the government wants to keep peace in Muslims region Sin kiang province (Salimi and Abadi, 2008).

From all above and the analysis we did about geopolitical facts, it's obvious that Islamic Republic of Iran has faced many challenges with countries in central Asia region and other regional and interregional actors in hard spectrum, USA and Israel and in soft spectrum China and Russia and that because of the differences between ideational structures between Iran and central Asia and actors. This difference in ideational structures has caused constitution of an opposite between ideal anarchic systems of IRI and dominated anarchic system of the region. This difference and IRI have low share in distribution of capabilities such as economical and military. For following its goals against, high level fruition enemies of IRI like USA, Israel and Russian, 
China competitors from distribution of capabilities in national and international caused many challenges and double-deficiency for IRI.

\section{CONCLUSION}

In this article, first we analyzed a constructivism approach and basic and floating geopolitical constructs, Coalition construct consist of self fulfilling and otherfulfilling, then, we analyzed regional and international anarchic system and structure and its features and it's compared with distribution of capabilities in international and regional structure. Then, we considered Iranian geopolitical constructs and presented internal construct. According to this: (1) ideational constructs of the central Asia region are different from basic geopolitical construct of Iran (expect some conditions); (2) in the other hand, some powerful actors like USA, Israel, turkey have floating constructs with some countries in the region (like Turkish culture and language, Hanafi Islam, secularism); (3) this differences between constructs have firmed and constituted oppositions between ideal anarchic system of IRI and the general one; 4. These differences in ideational structures and anarchic system have caused deficiency for making policy of IRI. In the region and also have destroyed the opportunities of geopolitical position and the interests of being neighbor; 5. Distribution of capabilities factor has aggravated the oppositions and challenges and as a result double-deficiency. So, the answer is: These differences in geopolitical constructs, between Iran and countries of central Asia region and also being harmonious construct, these countries with the present actors in the region, has caused an opposition in regional anarchic system between IRI and these countries in region and actors in the region and also form of distribution of capabilities between actors which has caused challenges for IRI.

\section{REFERENCES}

Akiner, S., 2003. The politicization of Islam in postsoviet Central Asia. Relig. State Soc., 31: 97-122. DOI: $10.1080 / 09637490308282$

Alimoradi, D., 2009. Israeli presence in Central Asia and Caucasus. IRTT.

Amirahmadiyan, B., 2003. Security in Azerbaijan Republic and Nato. Magiran. http://www.magiran.com/magarchive.asp?mgID=1367

Amirahmadiyan, B., 2008. Transport and transit in Central Asia. Center for Higher International Studies. http://www.pajouheshmag.ir/ppdf/5583/p05583000 20291-YVN2VO.pdf
Berger, P.L., J. Sacks, D. Martin, T. Weiming and G. Weigel et al., 1999. The Desecularization of the World: Resurgent Religion and World Politics. 1st Edn., Wm. B. Eerdmans Publishing Company, Washington DC., ISBN: 10: 0802846912, pp: 135.

Del Casino, Jr., V., 2009. Social Geography: A Critical Introduction. Wiley-Blackwell, USA., ISBN-10: 1405155000, pp: 336.

Esposito, J.L., 1990. The Iranian Revolution: Its Global Impact. 1st Edn., University Press of Florida, Florida, ISBN: 10: 0813010179, pp: 354.

Falahatpisheh, H., 2001. Security changes in Central Asia and Caucasus and Islamic Republic of Iran Security. Command and Staff College and Iranian Revolutionary Guards Publications.

Fuller, G., 1991. The Center of the Universe: The Geopolitics of Iran. 1st Edn., Westviews Press, Iran, ISBN: 9780813311586, pp: 301.

Hafeznia, M.R., 2001. Political Geography of Iran. SAMT.

Hafeznia, M.R., M.S. Dolatabadi and M.H. Afshordi, 2007. Iranian geopolitical interests in Central Asia and in confronting opportunities. Geopolitic. Q., 3: 78-119.

http://www.magiran.com/ppdf/5338/p0533800090 781-ZWP4WQ.pdf

Jenkins, R., 2004. Social Identity. 2nd Edn., Routledge, London, New York, ISBN: 10: 0415340969, pp: 232.

Jordan-Bychkov, T.G. and L. Rowntree, 1990. The Human Mosaic: A Thematic Introduction to Cultural Geography. 5th Edn., Harper and Row, Iran, ISBN: 0060434600, pp: 496.

Katouziyan, M.A.H., 2008. The political economy of Iran. Nashr-e-Markaz.

Kheyrandish, R. and S. Shayan, 1991. Stemming the name and flag of countries. Kavir Publication.

Kubalkova, V., 2001. Foreign Policy in a Constructed World. 1st Edn., M.E. Sharpe, Iran, ISBN: 10: 0765607883, pp: 302.

Lussac, S., 2008. The Baku-Tbilisi-Kars, railroad and its geopolitical implications for the South Caucasus. Caucasian Rev. Int. Affairs, 2: 212-224. httpp://cria-online.org/5_5.html

Matveeva, A., 1999. The Islamic challenge in postsoviet Eurasia. CA\&CC Press. http://www.cac.org/dataeng/04.matveeva.shtml

Mojtahezadeh, P. and M.R. Hafeznia, 2008. Equalization of political geography terms. Geopolit. Q., $\quad$ Q: $1-7$. http://www.magiran.com/ppdf/5338/p0533800110 011-EB4HB5.pdf

Moshirzadeh, H., 2007. Evolution in international relations theories. SAMT. 
Motaghi, E. and H. Kazemi, 2007. Constructivism, identity, language and foreign policy of the Islamic Republic of Iran. Polit. Q. J. Law Politic. Sci., 4: 201-237.

http://www.magiran.com/ppdf/5508/p0550800042 091-GD6JD7.pdf

Motahari, M., 1983. Mutual service of Islam and Iran. Sadra Publication.

Mousavi Khomeini, R., 1983. Seeking the path of imam word: Imam of the statements and notices from 1964-1982 years. Amir Kabir Publication.

Naghibzadeh, A., 2005. History of diplomacy and international relations: From the Westphalia treaty until today. Ghoomes Publication.

Norton, W., 2000. Cultural geography: Themes, concepts, analysis. Oxford Press.

Onuf, N.G., 1989. World of our making: Rules and rule in social theory and international relations. University of South Carolina Press.

Pirouz, Q.R., 2007. Shu'ubiyyaism: Equilibrium Model of Identity in Iran. In: Iranian Identity, Hayati, Z. and S.M.H. Moakhar (Eds.). Soureh Publication, Tehran, pp: 92-93.

Qotb, S., 1999. Road signs. Ehsan Publications.

Razi, A., 1948. The full history of Iran. Eghbal Publication.

Salimi, H. and M.H. Abadi, 2008. Security-political considerations of China in Central Asia (19912005). Central Eurasian Stud., 2: 87-102. http://www.pajouheshmag.ir/ppdf/5583/p05583000 20871-VSKYF9.pdf
Salimi, H., 2007. A constructivist approach to national identity in Iran. Natl. Stud. Q., 3: 34-34.

Shakouhi, H., 1994. Philosophy of geography. Gita Shenasi Publication.

Shakouhi, H., 2003. New ideas in philosophy of geography. Gita Shenasy Publication.

Shekari, A., 2006. The Keyhan newspaper study. Kayhannews. http://www.kayhannews.ir/arch.htm

Soja, E.W., 2008. Critical social theory, history: Geography: Modernity Talkhoun Publication.

Vaezi, M., 2007. Geopolitical crisis in the central Asia and Caucasus: the foundations and the actors. Ministry of Foreign Affairs.

Wendt, A., 1992. Anarchy is what states make of IT, the social construction of power politics. Int. Org., 46: 391-345. DOI: 10.1017/S0020818300027764

Wendt, A., 1994. Collective identity Formation and the international state. Am. Politic. Sci. Rev., 88: 384-396. http://www.jstor.org/pss/2944711

Wendt, A., 1999. Social theory of international politics. Cambridge University Press.

Yazdani, E., M. Touyserkani and S. Moradi, 2007. Geopolitical explanation of power competition, case study: Central Eurasia in new great game. Geopolitic. Q., 3: 147-147. 